\title{
39. A SEABEAM SURVEY OF THE LEG 67 AREA (MIDDLE AMERICA TRENCH OFF GUATEMALA) ${ }^{1}$
}

\author{
J. Aubouin, ${ }^{2}$ Jean-François Stephan, ${ }^{3}$ Vincent Renard, ${ }^{4}$ Jacqueline Roump,${ }^{3}$ and Peter Lonsdale ${ }^{5}$
}

\begin{abstract}
The results of a Seabeam survey allowed us to locate precisely Deep Sea Drilling Project Sites 494, 499, and 500, especially Hole 500 , drilled on the edge of a horst on the Cocos Plate, just in front of the subduction contact. The survey also shows that at its contact with the Middle America Trench, the Cocos Plate has a fault pattern oriented $140^{\circ} \mathrm{N}$, oblique to the Middle America Trench oriented $110^{\circ} \mathrm{N}$. That pattern is probably inherited from the birth of the Cocos Plate at the East Pacific Rise. The Trench axis is a succession of diamond-shaped basins in relation to the Cocos Plate structure. The subduction contact, just at the toe of the continental slope, is rectilinear, suggesting that there is no important slumping in the area.

In the Leg 67 area, the Cocos Plate falls into the subduction zone under the American continental margin, and extensional faulting accompanies this dive.
\end{abstract}

\section{INTRODUCTION}

The ship Jean Charcot made a short bathymetric survey with a multibeam sounder (Seabeam) of the Middle America Trench during a transit between Panama and Acapulco. A strip of the Trench approximately $3 \mathrm{~km}$ wide was surveyed continuously at the foot of the continental slope in the Leg 66 area (off Acapulco) and in the Leg 67 area (off Guatemala). Two of the areas completely surveyed are approximately $100 \mathrm{~km}^{2}$ (Leg 67) and $50 \mathrm{~km}^{2}$ (Leg 66) (Renard et al., 1980).

The Middle America Trench was previously surveyed (Fisher, 1961; Ladd et al., 1978), and a general bathymetric map is available for large parts of the Trench. But the precise Seabeam investigation has provided more information that allows a detailed discussion of the tectonic situation of the Leg 67 area.

\section{METHOD}

The contour intervals are 10 meters and were drawn in real time through a process perfected by the Centre Océanologique de Bretagne (C.O.B.) whereby the map can be drawn out directly in time with the progression of the ship. Nevertheless, the difficulties pertaining to navigation by satellite alone make it necessary to redefine the exact line of progression in order to produce the final document we present here (Fig. 3).

\section{GEOLOGICAL SETTING}

The Middle America Trench (Fig. 1), divided in two by the Tehuantepec Ridge, terminates in the southeast at the north end of the Cocos Ridge. It is defined by the subduction of the Cocos Plate in a mean northeast direction. The arrival of the Cocos Ridge in the Trench may have caused its restriction and the uplifting of the

\footnotetext{
${ }^{1}$ Aubouin, J., von Huene, R., et al., Init. Repts. DSDP, 67: Washington (U.S. Govt. Printing Office).

2 Département de Géotectonique, Université Pierre et Marie Curie, 75230 Paris, France.

3 Laboratoire d'Océanologie et Géodynamique, Université de Bretagne Occidentale, 29283 Brest, France.

4 Centre Océanologique de Bretagne, 29273 Brest, France.

${ }^{5}$ Scripps Institution of Oceanography, La Jolla, California.
}

continental margin at the Santa Elena and Nicoya peninsulas. In contrast, the arrival of the Tehuantepec Ridge in the Trench produced only a very slight deflection between the southern and northern parts, the former being not as deep as the latter, which reaches over 6000 meters water depth.

The Trench has two directions, approximately $140^{\circ} \mathrm{N}$ from the Nicoya peninsula up to El Salvador, approximately $115^{\circ} \mathrm{N}$ from El Salvador to Mexico; it must be noted that this curve has no connection with any structure known at present, either at sea or on land. Leg 67 holes were drilled in the southern part of the Trench, to the south of the Tehuantepec Ridge, in the section where the strike is $115^{\circ} \mathrm{N}$.

\section{DISCUSSION}

The margin of the Cocos Plate is Miocene (see Site 495 report, this volume) and is structured in a $130^{\circ} \mathrm{N}$ to $140^{\circ} \mathrm{N}$ direction. It shows a series of alternating, subrectilinear rises and swells, which seem to be horsts and grabens. This structural grain is parallel to the direction of the magnetic anomalies surveyed on the Cocos Plate in the neighborhood of the Leg 66 and Leg 67 study areas (Fig. 2). This orientation suggests that they are original structures connected with ocean spreading according to the model produced by the CYAMEX cruise on the East Pacific Rise (CYAMEX Scientific Team, 1980; Rangin and Francheteau, in press). Thus the tensional faults, although related to the flexure of the oceanic plate towards the Trench, repeat a structure inherited from the genesis of the Cocos Plate at the East Pacific Rise axis, as proposed for other areas (Luyendyk, 1970; Coulbourn and Moberly, 1977).

The Trench is sectioned into a succession of diamondshaped basins separated by bottlenecks. The basins correspond to the arrival into the Trench of the depressed parts of the Cocos Plate, and the bottlenecks to the arrival of the rises (Fig. 2). This structure is a clear consequence of the progressive burial of the Cocos Plate beneath the sedimentary filling of the Trench. 


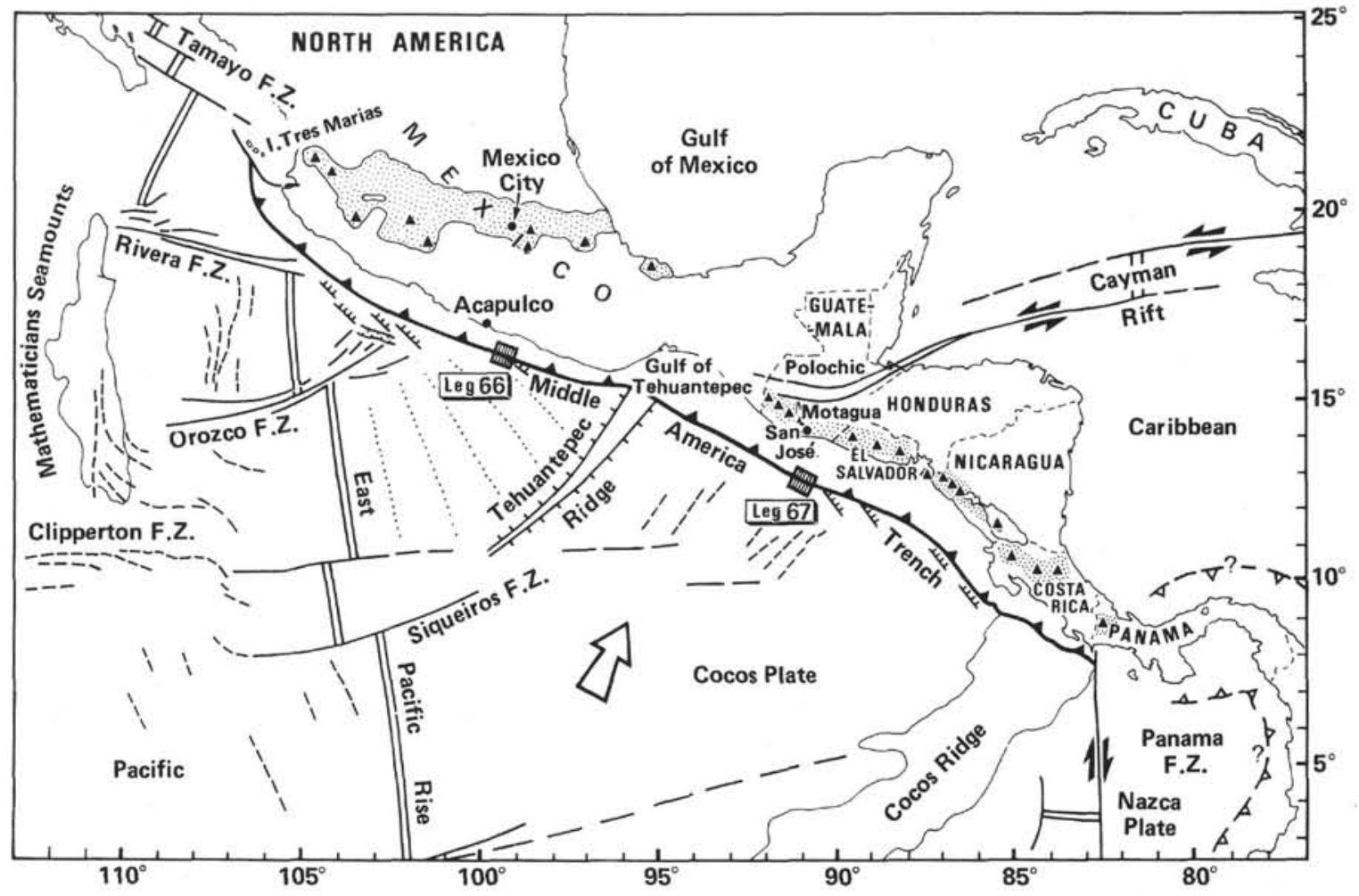

Figure 1. The Middle America Trench.

In the Leg 67 area the structure of the Trench is clearly derived from the burial of Cocos Plate structures. None of the detailed axial structures are related to the subduction in the Trench itself. Similar conclusions were drawn by Heezen and Rawson (1977) for the southern end of the Trench, and by Shipley et al. (1980) and Stephan et al. (in press) for the Leg 66 area. Here the subduction contact is located exactly at the toe of the continental slope.

The internal wall, on the continental side, is formed of steps of various heights. Above all, the toe is remarkably rectilinear: this seems to preclude the possibility of a recently slumped block from the continental slope. Hole 494A was drilled through an Upper Cretaceous to Recent sequence, in a correct position, at the foot of the continental slope. Therefore the possibility that it is a big block in a melange unit remains; however, its good stratigraphic order from the Upper Cretaceous through the Tertiary to the Present hardly agrees with this interpretation.

A first analysis shows that the steps on the continental slope are bounded by linear structures that intersect the contour intervals, suggesting vertical or subvertical faults. The aspect of the Middle America Trench is that of a graben. However, this faulting is secondary, in relation to the primary subduction process. Clearly, a trench with Miocene oceanic crust could not collapse from this Cretaceous continental margin; there is obviously a major contact at the foot of the continental slope. The seismic data show that it is the subduction contact. The collapse of the continental margin accompanies subduction; and the graben shape of the Trench is a consequence of subduction.
In the detail provided by this Seabeam survey (Fig. 3 ), one can see the positions of Site 494 on a small terrace, Site 500 at the toe of the internal wall just in front of the subduction contact, and Site 499 at the foot of the external wall. 6

The location of Site 500 is critical. It is situated just in front of the subduction contact at the southwestern edge of a horstlike hill coming into the Trench from the Cocos Plate. Thus one can understand the normal faulting observed in the cores as well as the fact that the oceanic crust is higher at Site 500 than at Site 499 . Just after the cruise, this horst, beneath the subduction contact, was drawn parallel to the direction of the Trench (Aubouin, von Huene et al., 1979; von Huene, Aubouin et al., 1980). Given the Seabeam results, the horst appears clearly to be the result of the Cocos Plate entering the Trench obliquely, as designated in Figure 4 (see Aubouin, von Huene, et al., 1981).

The oblique disposition of the features of the Cocos Plate provides a simple explanation for the large distribution of the terrigenous facies in the Pliocene-Pleistocene of the Trench axis (Site 495); if one accepts a longitudinal filling, one can understand more easily the transport of the terrigenous sediment through the external wall by the way of the grabenlike depressions.

On the internal wall, the detailed topography shows closed depressions on each terrace, which can certainly

\footnotetext{
6 The locations of the holes on the map are somewhat approximate because of two difficulties. First of all, Glomar Challenger and Jean Charcot both had satellite navigation systems. Secondly, the correction for sound velocity in the water is approximate in this zone, where the Matthews table gives no precise information and the choices on Glomar Challenger and too, greater for the Glomar Challenger data. Such problems can be solved in the future, if the Seabeam survey precedes the drilling.
Seater for the Glomar Challenger
} 


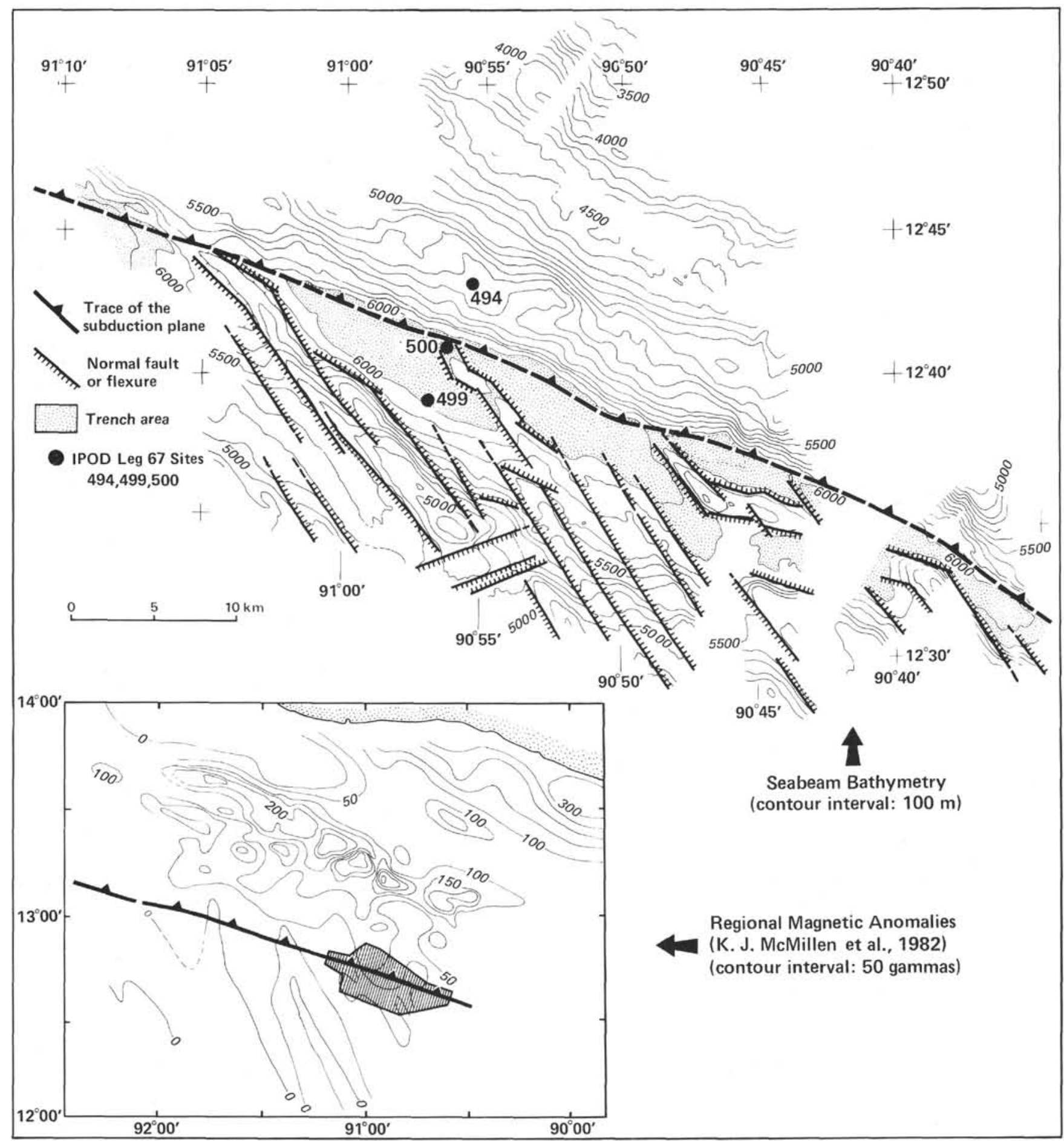

Figure 2. Sketch map (from K. J. McMillen et al., 1982) of the Leg 67 Sites 494, 499, and 500, interpreted from the Seabeam map (Fig. 3).

trap slope sediment; this could be a key for understanding the precise distribution of sediments between the slope and the Trench.

Certainly, the Seabeam map (Fig. 3) linked with the results of the Leg 67 drilling of the oceanic crust underlying the Trench, and with an appropriate piston coring of the terrigenous sediments across the Trench, could yield for the first time a very precise model of the complete sedimentation in the Trench.

\section{CONCLUSION}

Although this is a preliminary investigation, it seems possible to draw a certain number of conclusions from this Seabeam survey. The Cocos Plate structures are oriented $130^{\circ} \mathrm{N}$ to $140^{\circ} \mathrm{N}$, oblique to the Middle America Trench, which strikes $110^{\circ} \mathrm{N}$ to $115^{\circ} \mathrm{N}$, whereas the Plate enters the Trench axis perpendicularly. The result is a succession of diamond-shaped basins and bottle- 


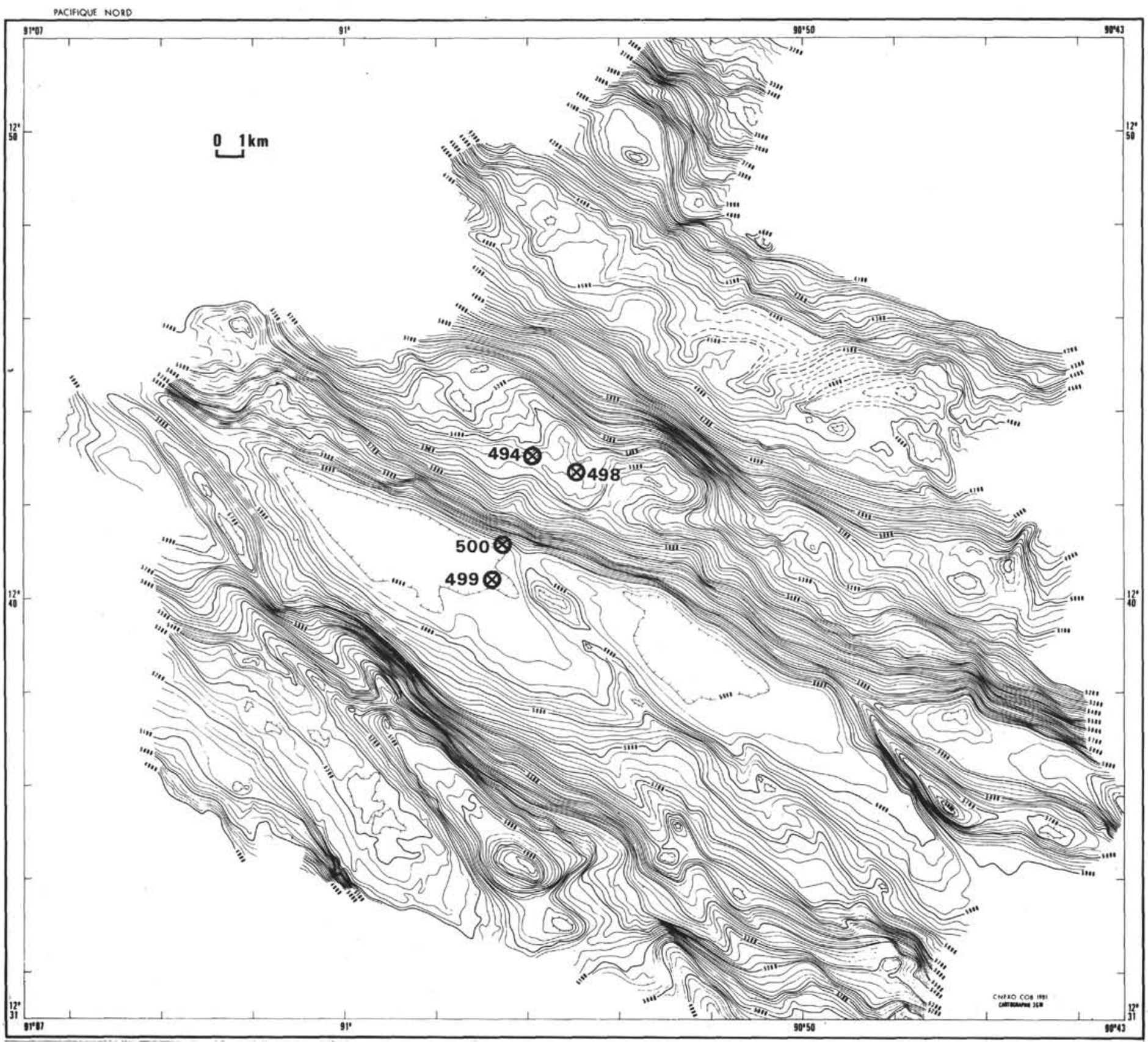

Figure 3. Seabeam map. 


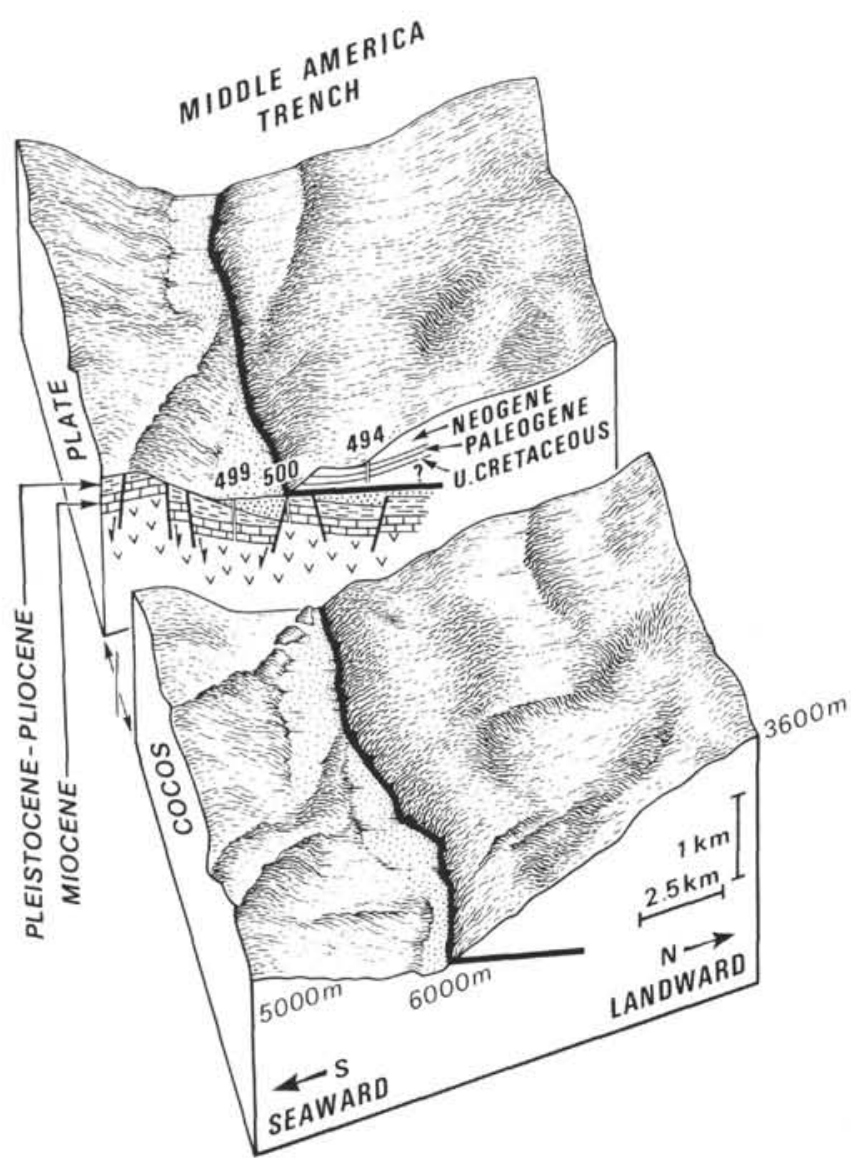

Figure 4. Block diagram of the Leg 67 sites discussed. (Water depths in meters are indicated.)

necks where the Plate dives towards the inner continental wall without having any effect on it, except an extensive downfaulting. It seems that the Cocos Plate "falls" into the subduction zone under the American continental margin and that extensional faulting accompanies this dive.

The mid-America margin structures may be ancient (Upper Cretaceous) and are distinct from those of the Cocos Plate (Miocene). Leg 67 drilling results indicate the subduction contact is between two plates, each with their own tectonic history. The Seabeam map supports this assessment.

So it seems that there is no accretionary process presently working in the Middle America Trench in the Leg 67 area. Off Guatemala, relative plate motion is predominantly subduction normal to the Trench axis, but it appears to be accompanied by a collapse of the continental margin as evidenced by the downfaulted benches.

The tectonic structure of the IPOD transect across the Middle America Trench off Guatemala is but one of the many structures that exist along subduction zones. Given a different vector and rate of convergence, a thicker sequence of sediment in the Trench, or a different age of the oceanic plate, the resulting tectonic structure might have taken a much different form, as is seen along the Middle America Trench to the north, where accretion is presently a dominant process (Stephan et al., in press). That there is such a difference between this northern area of the Trench and the Guatemalan margin might be attributed to some of these factors: in the Leg 66 area, the Cocos Plate entering the Trench is younger (late Miocene); the convergence rate is lower because of the rotation of the Cocos Plate; and the sedimentary filling is very much thicker (observed in the drilling) in relation to the absence of a fore-arc basin trapping the sediments, as in the Leg 67 area. These diverse results suggest that the Middle America Trench provides an interesting example of the various tectonic effects of subduction.

\section{REFERENCES}

Aubouin, J., and Blanchet, R., 1981. Subduction and tectonics. In 26th Intern. Geol. Congr., Paris, Colloque C3: Geology of continental margins. Oceanol. Acta, Suppl. Vol. 4:283-294.

Aubouin, J., von Huene, R., Azéma, J., Coulbourn, W. T., Cowan, D. S., Curiale, J. A., Dengo, C. A., Faas, R. W., Harrison, W., Hesse, R., Ladd, J. W., Musylöv, N., Shiki, T., Thompson, P. R., and Westberg, J., 1979. Premiers résultats des forages profonds dans le Pacifique au niveau de la fosse du Guatemala (fosse d'Amérique Centrale) (Leg 67 du "Deep Sea Drilling Project": MaiJuin 1979). C. R. Acad. Sci. Ser. D, 289:1215-1220. in press. A summary of Deep Sea Drilling Project Leg 67. Shipboard results from the Mid-America Trench transect off Guatemala. In 26th Intern. Geol. Congr., Paris, Colloque C3: Geology of continental margins. Oceanol. Acta, 89:225-232.

Coulbourn, W. T., and Moberly, R., 1977. Structural evidence of the evolution of fore-arc basins off South America. Can. J. Earth Sci., 14:102-116.

CYAMEX Scientific Team, 1980. First manned submersible dives on the East Pacific Rise at latitude $21^{\circ} \mathrm{N}$ (Project Rita). General results. Mar. Geophys. Res., 4:345-379.

Fisher, R. L., 1961. Middle America Trench: topography and structure. Geol. Soc. Am. Bull., 72:703-720.

Heezen, B. C., and Rawson, M., 1977. Visual observations of the seafloor subduction line in the Middle America Trench. Science, 196: 423-426.

Karig, D. E., Cardwell, R. K., Moore, G. F., and Moore, D. G., 1978. Late Cenozoic subduction and continental margin truncation along the northern Middle America Trench. Geol. Soc. Am. Bull., 89: 265-276.

Ladd, J. W., Ibrahim, A. K., McMillen, K. J., Latham, G. V., von Huene, R. E., Watkins, J. S., Moore, J. C., and Worzel, J. L., 1978. Tectonics of the Middle America Trench, offshore Guatemala. Intern. Symp Guatemala 4 Feb. Earthquake and Reconstruction Process, Guatemala City, 1.

Luyendyk, B. P., 1970. Origin and history of abyssal hills in the Northeast Pacific Ocean. Geol. Soc. Am. Bull., 81:2237-2260.

McMillen, K. J., Enkeball, R., Moore, J. C., Shipley, T., and Ladd, J., 1982. Sedimentation in two different tectonic environments of the Middle America Trench, southern Mexico and Guatemala. In Leggett, J. (Ed.), Trench and Fore-Arc Sedimentation in Modern and Ancient Subduction Zones: Geol. Soc. of London Special Publication.

Rangin, C., and Francheteau, J., in press. Fine-scale morphological and structural analysis of the East Pacific Rise $21^{\circ} \mathrm{N}$ (Rita project). Oceanol. Acta.

Renard, V., Aubouin, J, Lonsdale, P., and Stephan, J. F., 1980. Premiers résultats d'une etude de la fosse d'Amerique centrale au sondeur multifaisceaux (Seabeam). C. R. Acad. Sci. Ser. D, 291: 137-142.

Seely, D. R., 1979. Geophysical investigations of continental slopes and rises. In Watkins, J. S. and Montadert, L. (Eds.), Geological and Geophysical Investigations of Continental Margins. Am. Assoc. Pet. Geol. Mem., 29:245-260.

Seely, D. R., Vail, P. R., and Walton, G. C., 1974. Trench slope model. In Burk, C. A., and Drake, C. L. (Eds.), The Geology of Continental Margins: New York (Springer-Verlag), pp. 249-260.

Shipley, T. H., McMillen, K. J., Watkins, J. S., Moore, J. C., Sandoval-Ochoa, J. H., and Worzel, J. L., in press. Continental mar- 
gin and lower slope structures of the Middle America Trench near Acapulco (Mexico). Mar. Geol., 35:65-82.

Stephan, J. F., Aubouin, J., Roump, J., and Renard, V., in press. Results of a Seabeam survey in the Leg 66 area. In Watkins, J. S., Moore, J. C., et al., Init. Repts. DSDP, 66: Washington (U.S. Govt. Printing Office). von Huene, R., Aubouin, J., Azéma, J., Blackinton, G., Carter, J. A., Coulbourn, W. T., Cowan, D. S., Curiale, J. A., Dengo, C. A., Faas, R. W., Harrison, W., Hesse, R., Hussong, D. M., Ladd, J. W., Muzylöv, N., Shiki, T., Thompson, P. R., and Westberg, J., 1980. DSDP Mid-America Trench transect off Guatemala. Geol. Soc. Am. Bull., 91, Pt. 1:421-432. 